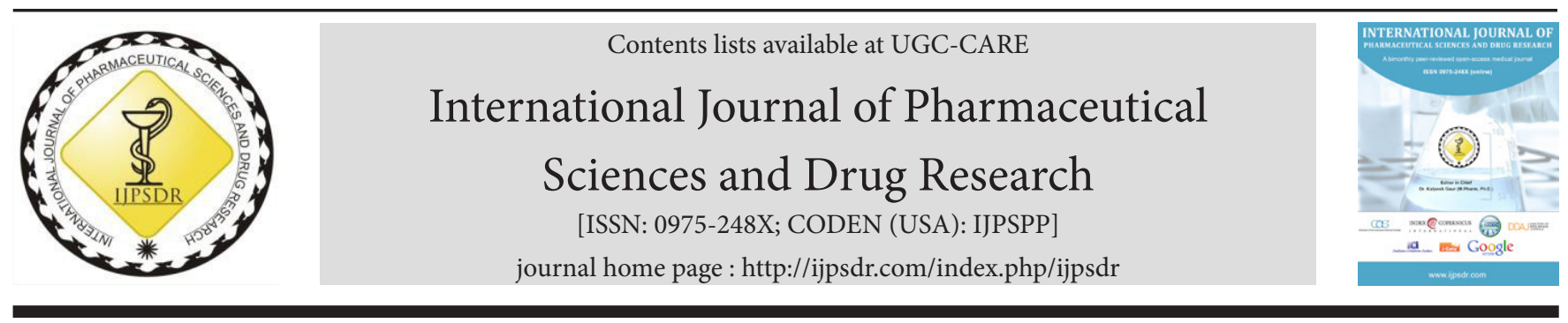

Research Article

\title{
Evaluation of Mutagenic and Antimutagenic Activity of Methanol Extract of Cousinia thomsonii against Cyclophosphamide
}

\author{
Ishfaq S. Khan ${ }^{1 *}$, Khalid Bashir ${ }^{2}$, Naveed Gulzar ${ }^{1}$, Yaseen M. Bhat ${ }^{3}$ \\ ${ }^{1}$ Cytogenetics and Molecular Biology Research Laboratory, University of Kashmir, Srinagar-190006, Jammu and Kashmir, India \\ ${ }^{2}$ Department of Clinical Biochemistry, University of Kashmir, Srinagar-190006, Jammu and Kashmir, India \\ ${ }^{3}$ Department of Botany, University of Kashmir, Srinagar-190006, Jammu and Kashmir, India
}

\begin{tabular}{l} 
A R T I C L E I N F O \\
\hline Article history: \\
Received: 23 October, 2019 \\
Revised: 10 January, 2020 \\
Accepted: 20 January, 2020 \\
Published: 30 January, 2020 \\
Keywords: \\
Cousinia thomsonii, \\
Cyclophosphamide, \\
Micronucleus, \\
Mitotic index. \\
D0I: \\
10.25004/IJPSDR.2020.120109
\end{tabular}

\section{INTRODUCTION}

The use of medicinal herbs is certainly as ancient as human beings themselves. Over 150,000 species of plants have been studied, many of which contain medicinal substances. During earlier times, phytotherapy was considered as one of the best forms of clinical practice to treat, heal, and prevent general disorders. ${ }^{[1]}$ Herbal and natural treatments are projected to account for about $25 \%$ in developed nations and around $80 \%$ in developing nations. The total amount of plant species with chemopreventive properties approaches one lakh, but the actual figure could be much greater because only $10-20 \%$ of plants have been analyzed till now. ${ }^{[2]}$ Much emphasis has recently been focused on the use of naturally occurring substances in food and medicinal plants. Reports of the protection and toxicity of plants used in therapy are important because of their vast range of applications and their common use in folk medicine, which is often the only therapy of many cultures and ethnic groups. ${ }^{[3]}$ Many phytotherapy experiments have already shown that most compounds of medicinal plants have detrimental effects such as mutagenicity, carcinogenicity, and toxicity. Therefore these drawbacks limit their use as therapeutic agents. ${ }^{[4,5]}$ Despite the fact that the beneficial uses of medicinal plants, many chemicals present in plants may show mutagenic effects due to their ability to produce genomic changes, which subsequently results in severe health issues. Hence, it is necessary to check the mutagenicity of plant constituents to ensure the value of medicinal

\footnotetext{
*Corresponding Author: Mr. Ishfaq Shafi Khan

Address: Cytogenetics and Molecular Biology Research Laboratory, University of Kashmir, Srinagar-190006, Jammu and Kashmir, India

Email $₫$ : ishfaqshafi929@gmail.com

Tel.: +91-9419049877

Relevant conflicts of interest/financial disclosures: The authors declare that the research was conducted in the absence of any commercial or financial relationships that could be construed as a potential conflict of interest.

Copyright (C) 2020 Ishfaq Shafi Khan et al. This is an open access article distributed under the terms of the Creative Commons AttributionNonCommercial-ShareAlike 4.0 International License which allows others to remix, tweak, and build upon the work non-commercially, as long as the author is credited and the new creations are licensed under the identical terms.
} 
compounds. ${ }^{[6,7]}$ Many assays are being used to assess the genotoxicity of test chemicals in both in-vivo and in-vitro conditions. Some parameters like micronucleus formation, chromosome abnormalities, and mitotic index, are routinely used in genotoxicity evaluation. ${ }^{[8,9]}$

Cousinia thomsonii (CT) is a perennial herb of family Asteraceae. It is commonly referred to as 'Thomsons Thistle' in English and 'Megtham' in Ladakhi language. It is an erect spinny thistle-like plant, with cottony stem, pinnately lobed spiny leaves, and with large round purple flowers. It is 1 feet 6 inch long hermaphrodite plant with flowering season in the month of July to September. Its distribution extends from Afghanistan to western Nepal, and Tibet. It is also found at high elevations 3000 to 4200 meters of Ladakh and Lahul of Jammu and Kashmir. It has been found that dried root powder of CT cure severe joint pains. ${ }^{[10,11]}$ It is also found effective in curing headache, stomach problems, measles, and boils. There is very scarce literature present regarding this plant, and little information is available about the biological effects of its constituents. No report has been found in the literature regarding the genotoxicity of CT in prokaryotic or eukaryotic mutation assay. In the present research work, the mutagenic and antimutagenic effect of CT extract was determined using micronucleus and chromosomal aberration assays. The MI and PCE/NCE ratio were also calculated to determine its toxic status.

\section{MAterials AND METHODS}

\section{Chemicals}

All chemicals used in this experiment were of high analytical grade.

\section{Collection and Extraction of Plant Material}

Collection of the plant was done in September 2018 from higher areas of Ladakh, J and K, India, and sent to Taxonomy center, Botany Department, University of Kashmir for identification. The identification was made based on the morphological features of the plant. A reference specimen has been stored for future reference in the herbarium of the Botany Department, Kashmir University. About $75 \mathrm{~g}$ of powder was extracted from the whole plant with $400 \mathrm{~mL}$ of methanol with the help of a Soxhlet extractor. Under reduced pressure, the methanol residue was removed from the extract by rotary evaporator, and the final extract was then stored for further analysis in the refrigerator.

\section{Experimental Animals}

In our study 30 Wistar strain male albino rats about 130-180 g in weight were used. These rats were purchased from the Indian Institute of Integrative Medicine (IIM), Canal Road, Jammu. The animals were kept in stainless steel cages in the animal house of the Zoology Department, University of Kashmir, under laboratory conditions of $24 \pm 2{ }^{\circ} \mathrm{C}$, and $12 / 12$ hours of light and dark cycle. At the initiation of the experiment, all animals were first acclimatized for about one week and were starved for 50 minutes. The Committee on Institutional Animal Ethics approved the research protocol, and the experiment was done under standard ethical principles.

\section{Dosage and Design of Experimental Animals}

The 30 male rats were randomly distributed into 6 groups, with 5 rats per group. The animals from each group were carefully weighed before the start of experiment and at the end of experiment. The dose was given mostly in the morning time between 10.00-11.00 a.m. The animals were treated with the CT extract and CP orally at different doses by oral gavage intubation. The animals were starved for about 12 hours before the start of the treatment protocol. The first day when the animals were treated with the plant extract was counted as experimental day one.

Group 1: (control group) treated with olive oil and distilled water for 20 days.

Group 2: (positive control) treated with (CP) at a dosage of $60 \mathrm{mg} / \mathrm{kg} \mathrm{b}$ wt. for 2 days.

Group 3: Treated with $100 \mathrm{mg} / \mathrm{kg}$ b wt./day of CT extract orally for 20 days.

Group 4: Treated with $200 \mathrm{mg} / \mathrm{kg}$ b wt./day of CT extract for 20 days.

Group 5: Treated with $100 \mathrm{mg} / \mathrm{kg} \mathrm{b}$ wt. of CT extract for first 18 days and for remaining 2 days with CP $(60 \mathrm{mg} /$ kg b wt.).

Group 6: Treated with $200 \mathrm{mg} / \mathrm{kg} \mathrm{b}$ wt. of CT extract for first 18 days and for remaining 2 days with CP $(60 \mathrm{mg} /$ kg b wt.).

\section{Chromosomal Aberration (CA) Assay}

The protocol of Preston $\mathrm{RJ}^{[12]}$ was used for the analysis of chromosomal abnormalities. Briefly, rats were treated with $0.5 \mathrm{~mL}$ of $0.06 \%$ colchicine intraperitoneally 3 hours before cervical dislocation in order to stop cells at the metaphase stage. In a centrifuge tube, the bone marrow from both femur bones was removed in $5 \mathrm{~mL} \mathrm{KCl}$ solution and incubated at $35^{\circ} \mathrm{C}$ for about 20 minutes. Centrifugation of the cell suspension was done at $1000 \mathrm{rpm}$ for 5 minutes, and the supernatant formed was discarded. The pellets component formed was suspended in $5 \mathrm{~mL}$ Carnoy's fixative (glacial acetic acid and methanol in the ratio of 1:3). The centrifugation and fixation process was repeated many times. Slides were then designed, stained by Giemsa solution (5\%), and microscopically displayed by using a fluorescence microscope. To determine the number of chromosome aberrations, one hundred metaphasic cells per animal were analyzed.

\section{Micronucleus Assay (MA)}

Analysis of micronucleated cells from the bone marrow of rats was made by the method of Von Ledebur $\mathrm{M}$, et al. ${ }^{[13]}$ Bone marrow cells from femur bones were removed with calf serum (fetal) and the mixture was centrifuged at 
$1000 \mathrm{rpm}$ for 15 minutes. The pellets were spread on a sterilized glass slide and fixed with absolute methanol. Staining of the slides was done by undiluted May Grunwald stain for 3 minutes, then diluted May Grunwald stain for 2 minutes, and at last with $10 \%$ Giemsa stain for 10 minutes. Two thousand PCE were analyzed from each animal to check for the presence of micronucleus. The proportion of PCE to NCE from 1000 erythrocytes per rat was also evaluated to detect the toxic effects.

\section{RESULTS}

Tables 1-3 show the parameters like micronucleus assay, PCE/NCE ratio, mitotic index, and chromosomal aberrations in bone marrow Wistar rats when treated with $\mathrm{CP}, \mathrm{CT}$ extract alone, and combination of CT extract and CP. It was found that $\mathrm{CP}$ treated group 2 rats produce a highly significant change in the formation of micronucleated erythrocytes and reduction of PCE/NCE ratio in comparison to the control group. However, it was found that CT extract did not produce any significant micronucleated cell at a dosage of 100 and $200 \mathrm{mg} / \mathrm{kg}$ b wt. Similarly, treatment of group 5 and 6 with CT extract in combination with CP show protective effects by reducing micronucleus formation at both concentrations in a dose-dependent manner. It was also found that CT extract alone or in combination with CP improve the PCE/NCE ratio nearly above one.

The results of the micronucleus assay (MA) and PCE/ NCE ratio are shown in Table 1. The mean value of MnPCE and PCE/NCE ratio in control rats (Group I) was found to be $2.20 \pm 1.30$ and 2.50 respectively. As expected in Group 2 (CP treated) the value of MnPCE and PCE/NCE ratio was $32.20 \pm 3.49$ and 0.42 . However, $\mathrm{CT}$ extract, in combination with CP reduces the value of MnPCE from $32.20 \pm 3.49$ to $6.20 \pm 1.78$ in group 5 and to $3.60 \pm 0.89$ in group 6 rats.

The result of the MI is shown in Table 2. MI was calculated by considering 1000 cells/ animal ( $n=5$ /group).

Table 1: Frequency of micronucleated polychromatic erythrocytes and PCE/NCE in bone marrow cells of male wistar rats exposed to varying doses of Cousinia thomsonii extract alone and in combination with cyclophosphamide.

\begin{tabular}{|c|c|c|c|c|c|c|c|c|}
\hline \multirow{2}{*}{$\begin{array}{l}\text { Groups } \\
\text { Group } 1\end{array}$} & \multirow{2}{*}{$\begin{array}{l}\text { Concentration } \\
\text { Olive oil (negative control) }\end{array}$} & \multicolumn{5}{|c|}{ No. of MNPCE per animal } & \multirow{2}{*}{$\begin{array}{l}M N P C E \\
( \pm S D) \\
2.20 \pm 1.30\end{array}$} & \multirow{2}{*}{$\frac{P C E / N C E}{2.50}$} \\
\hline & & 4 & 2 & 1 & 1 & 3 & & \\
\hline Group 2 & Cyclophosphamide $60 \mathrm{mg} / \mathrm{kg}$ & 30 & 38 & 33 & 30 & 30 & $32.20 \pm 3.49^{* *}$ & 0.42 \\
\hline Group 3 & $\mathrm{CT}$ extract $100 \mathrm{mg} / \mathrm{kg}$ & 3 & 4 & 0 & 3 & 3 & $2.60 \pm 1.51^{\#}$ & 1.22 \\
\hline Group 4 & CT extract $200 \mathrm{mg} / \mathrm{kg}$ & 0 & 4 & 3 & 2 & 2 & $2.20 \pm 1.48^{\#}$ & 1.59 \\
\hline Group 5 & CT extract $100 \mathrm{mg}+\mathrm{CP} 60 \mathrm{mg} / \mathrm{kg}$ & 8 & 8 & 4 & 5 & 6 & $6.20 \pm 1.78^{* *}$ & 1.00 \\
\hline Group 6 & $\mathrm{CT}$ extract $200 \mathrm{mg}+\mathrm{CP} 60 \mathrm{mg}$ & 4 & 3 & 5 & 3 & 3 & $3.60 \pm 0.89^{\#}$ & 1.04 \\
\hline
\end{tabular}

$\mathrm{CT}=$ Cousinia thomsonii, $\mathrm{CP}=$ Cyclophosphamide.

Values were represented as mean \pm SD with 5 rats per group at $\mathrm{p}<0.05$.

"Significant $(\mathrm{p}<0.05),{ }^{* *}$ highly significant $(\mathrm{p}<0.01)$, " non-significant $(\mathrm{p}>0.05)$.

Table 2: Frequency of mitotic index (MI) in bone marrow cells of male Wistar rats exposed to different doses of Cousinia thomsonii extract alone and in combination with cyclophosphamide.

\begin{tabular}{lllll}
\hline Groups & Concentration & Cells counted & No. of dividing cells & Mitotic index \pm SD) \\
\hline Group 1 & Olive oil (negative control) & 1000 & 932.40 & $93.24 \pm 2.66$ \\
Group 2 & Cyclophosphamide 60 mg/kg & 1000 & 568.00 & $56.80 \pm 3.96^{* *}$ \\
Group 3 & CT extract 100 mg/kg & 1000 & 892.00 & $89.20 \pm 0.83^{\#}$ \\
Group 4 & CT extract 200 mg/kg & 1000 & 921.00 & $92.10 \pm 1.59^{\#}$ \\
Group 5 & CT extract 100 $\mathrm{mg}+$ CP $60 \mathrm{mg} / \mathrm{kg}$ & 1000 & 746.00 & $74.60 \pm 5.54^{* *}$ \\
Group 6 & CT extract 200 $\mathrm{mg}+\mathrm{CP} 60 \mathrm{mg}$ & 1000 & 828.00 & $82.80 \pm 6.76^{* *}$ \\
\hline
\end{tabular}

$\mathrm{CT}=$ Cousinia thomsonii, $\mathrm{CP}=$ Cyclophosphamide.

Values were represented as mean \pm SD with 5 rats per group at $\mathrm{p}<0.05$.

*Significant $(\mathrm{p}<0.05),{ }^{* *}$ highly significant $(\mathrm{p}<0.01)$, \# non significant $(\mathrm{p}>0.05)$.

Table 3: Frequency of chromosomal aberrations observed in bone marrow cells of male Wistar rats treated with different doses of Cousinia thomsonii extract alone and in combination with cyclophosphamide.

\begin{tabular}{lllllllll}
\hline Groups & Concentration & Polyploidy & Rings & Breaks & Fragments & Stickiness & Disorientation & Total abnormality \\
\hline Group 1 & Olive oil (Negative control) & $1.0 \pm 0.0$ & $0.4 \pm 0.54$ & $0.0 \pm 0.0$ & $0.2 \pm 0.44$ & $0.6 \pm 0.54$ & $0.4 \pm 0.54$ & $2.16 \pm 1.72$ \\
Group 2 & Cyclophosphamide 60 mg/kg & $10.6 \pm 2.40$ & $9.0 \pm 2.12$ & $7.8 \pm 1.64$ & $7.0 \pm 1.58$ & $7.8 \pm 0.83$ & $7.8 \pm 1.48$ & $41.66 \pm 6.40^{* *}$ \\
Group 3 & CT extract 100 mg/kg & $2.2 \pm 0.83$ & $1.4 \pm 1.14$ & $0.4 \pm 0.54$ & $1.4 \pm 1.14$ & $1.4 \pm 0.54$ & $1.2 \pm 0.44$ & $6.66 \pm 2.87^{*}$ \\
Group 4 & CT extract 200 mg/kg & $2.0 \pm 0.70$ & $1.2 \pm 1.09$ & $0.2 \pm 0.44$ & $1.2 \pm 1.30$ & $1.2 \pm 0.83$ & $1.0 \pm 0.0$ & $5.66 \pm 2.87^{*}$ \\
Group 5 & CT extract 100 mg + CP 60 mg/kg & $2.6 \pm 0.89$ & $2.0 \pm 1.0$ & $1.0 \pm 0.0$ & $2.0 \pm 1.22$ & $1.6 \pm 0.89$ & $1.6 \pm 0.89$ & $9.00 \pm 2.68^{* *}$ \\
Group 6 & CT extract 200mg + CP 60mg & $2.4 \pm 0.54$ & $1.6 \pm 0.89$ & $0.6 \pm 0.54$ & $1.2 \pm 1.30$ & $1.8 \pm 0.44$ & $1.4 \pm 0.54$ & $7.50 \pm 3.01^{* *}$ \\
\hline
\end{tabular}

$\mathrm{CT}=$ Cousinia thomsonii, $\mathrm{CP}=$ Cyclophosphamide.

Values were represented as mean \pm SD with 5 rats per group at $\mathrm{p}<0.05$.

${ }^{*}$ Significant $(\mathrm{p}<0.05),{ }^{* *}$ highly significant $(\mathrm{p}<0.01),{ }^{*}$ non-significant $(\mathrm{p}>0.05)$. 
It was found that MI in control rats (group I) was $93.24 \pm$ 2.66. As expected, rats treated with CP produce a highly significant reduction in MI $56.80 \pm 3.96$ when compared with control rats. In groups 3 and 4 rats treated with CT extract at a dosage of 100 and $200 \mathrm{mg} / \mathrm{kg}$, there was not found any significant change in MI when a comparison was made with control rats (group 1). However, group 5 and 6 animals, when treated with CT extract in combination with CP, a protective effect was found by increasing the MI in a dose-dependent manner.

The results of CA induced by CP, CT extract, and CT extract $+\mathrm{CP}$ are shown in Table 3. CAs were calculated by taking 100 cells per animal (total of 500 cells per group, $n=5$ ). The different kinds of aberrations that were observed in our experiment are polyploidy, ring chromosomes, chromosome breaks, chromosome fragments, metaphase stickiness, and chromosome disorientation. It was found that group 2 rats treated with CP produce a highly significant increase in total chromosome abnormality when compared with the control group. Total abnormality found in group 2 was $41.66 \pm 6.40$. CT extract treatment in groups 3 and 4 rats produce only slight changes in chromosomal aberrations at the dose concentration of 100 and $200 \mathrm{mg} / \mathrm{kg}$ when compared with the control group. However, when groups 5 and 6 rats were treated with CT extract in combination with $\mathrm{CP}$, a protective effect was observed as manifested by the reduction in total chromosomal abnormality. The protective effect was found more significant at a high dose of extract.

\section{DiscusSiON}

For the beneficial use of plant products as pharmacological and chemopreventive agents, it is mandatory to investigate more carefully their actual antimutagenic potential in-vivo in connection with other antimutagenic factors. Most of the higher plants contain a variety of compounds or phytoconstituents that can mitigate the mutagenic effects of a particular chemical. ${ }^{[14]}$ The main aim of our current work was to determine the genotoxicity of CT extract against CP induced chromosomal damage using bone marrow of wistar rats. Generally, changes in basic chromosomal architecture are considered good markers for estimating the mutagenic potential of a particular chemical. Some parameters like MnPCE, MI, PCE/NCE, and $\mathrm{CA}$ are being widely used to determine the cytotoxicity of chemicals. MI, which is an important parameter used to calculate the number of active dividing cells, should be neither too low nor too high when compared with the negative control. MI lower than control represents a low rate of cell proliferation, and higher than normal control represents an uncontrolled dividing rate of cells, which will ultimately lead to tumor formation. ${ }^{[15]}$

In our study, the cytological investigation showed that a significant reduction in MI was seen in rats treated with CP. However, treatment of animals with CT extract alone and in combination with CP shows no major changes in MI when compared with control-treated rats. The restoration of MI in CT treated rats against CP shows the protective effect of CT extract against mitotic depression. The different kinds of chromosomal aberrations induced by $\mathrm{CP}$ observed in our experiment were polyploidy, rings, breaks, fragments, stickiness, and disorientation. Cytotoxicity of CP was seen in the form of a reduction in PCE/NCE ratio and MI. Moreover, MnPCE and CAs were also observed at a high rate. CT extract alone at different doses did not produce any sign of mutagenicity in respect of MnPCE, CAs, MI, and PCE/NCE ratio. However, CT extract, in combination with $\mathrm{CP}$ shows protective antimutagenic effects against the CP damage by changing values of MnPCE, CAs, MI, and PCE/NCE ratio to negative control.

Different types of research findings were performed from time to time to investigate the mutagenic and antimutagenic potential of plant extracts, and our present experimental outcomes go in accordance with those findings. Negative genotoxicity was observed in bone marrow cells and peripheral blood of Wistar rats when treated with Solanum melongena extract. ${ }^{[16]}$ Later on same antimutagenic effects and protection were observed when Solanum melongena extract was given in combination with doxorubicin to Wistar rats. ${ }^{[17]}$

The mushroom, Agaricus blazei was found to produce protection against cyclophosphamide-induced genotoxicity in rats. It was also found that three different tea extracts of Agaricus significantly lowers the rate of micronucleus formation in polychromatic erythrocytes and reticulocytes. ${ }^{[18]}$ The antimutagenic behavior against 2-acetylaminofluorine and aflatoxin $\mathrm{B}_{1}$ by the aqueous extracts of rooibos tea (Aspalathus linearis) and honey-bush tea (Cyclopia intermedia) was observed. ${ }^{[19]}$ The phytochemicals derived from the bark of Terminalia arjuna prevented the mutagenic effects of aromatic amine, 2-aminofluorene (2-AF) and inhibited the metabolic activation of this pro-mutagen into mutagen. ${ }^{[20]}$ In a similar observation, it was found that the methanol extract of Rhizoplaca chrysoleuca produces antigenotoxic effects against known mutagen sodium azide. ${ }^{[21]}$ The different plant extracts also have antimutagenic effects against the mutagenicity of cyclophosphamide in mice. ${ }^{[22]}$

In another study, it was found that the different concentrations of Dioscorea pentaphylla significantly inhibit the mutagenic effects induced by a potent mutagen methyl methanesulphonate (MMS). ${ }^{[23]}$ They also found that the methanolic extract was highly antimutagenic in comparison to petroleum ether and chloroform. Thus, due to non-mutagenic effects and protection against known mutagens, CT can provide a rationale for use in chemotherapeutic medicine.

\section{CONCLUSION}

Some important metabolites such as alkaloids, antibiotics, terpenoids, saponins, quinolines, and some glycoproteins are derived from plants. Lower plants play an important role in the prevention of different diseases. From the 
present work, it was proved that CT did not show any mutagenic effect, but in turn, shows protection against potent mutagen cyclophosphamide.

\section{REFERENCES}

1. Halberstein RA. Medicinal Plants: Historical and Cross Cultural Usage Patterns. Annals of Epidemiology. 2005;15(9):686-686.

2. Wink M. Functions and biotechnology of plant secondary metabolites. Annual Plant Reviews. 2009;39:1-20.

3. Maciel MAM, Pinto AC, Veiga VF, Grynberg NF, Echevarria A. Plantas medicinais: a necessidade de estudos multidisciplinares. Quim Nova. 2002;25(3):429-438.

4. Déciga-Campos M, Rivero -Cruz I, Arriaga-Alba M, Castaneda-Corral G, Angeles-López GE, Navarrete A and Mata R. Acute toxicity and mutagenic activity of mexican plants used in traditional medicine. Journal of Ethnopharmacology. 2007;110(2):334-342.

5. Marques RCP, Medeiros SRB, Dias CS, Barbosa -Fil ho JM and AgnezLima LF. Evaluation of the mutagenic potential of yangambin and of the hydroalcoholic extract of Ocotea duckei by the Ames test. Mutatation Research. 2003;536:117-120.

6. Celik TA, Aslanturk OS. Anti-mitotic and anti-genotoxic effects of Plantago lanceolata aqueous extracts on Allium cepa root tip meristem cells. Biologia. 2006;61(6):693-697.

7. Negrelle RRB, Gomes EC. Cymbopogon citratus (D.C) Stapf: chemical composition and biological activities. Revista Brasileira de Plantas Medicinais. 2007;9(1):80-92.

8. Sansebastian JR, Lucenti SM, Mecca D, Giglio T, Madison N, Gongliewski N, Messina D, Ciotalo VB, Matthews RJ. Micronucleus test (MNT) and chromosomes aberrations (CA) from a single animal. Environmental Molecular Mutagenesis. 1990;15(17):52.

9. Krishna G, Kropko ML, Ciaravino V, Theiss JC. Simultaneous micronucleus and chromosomes aberration assessment in the rat. Mutation Research Letters. 1991;264(1):29-35.

10. Singh KN. Traditional knowledge on ethnobotanical uses of plant biodiversity: a detailed study from the Indian western Himalaya. Biodiversity Research and Conservation. 2012;28:63-77.

11. Sharma PK, Thakur SK, Manuja S, Rana RK, Kumar P, Sharma S, Chand J, Singh A, Katoch KK. Observations on Traditional Phytotherapy among the Inhabitants of Lahaul Valley through Amchi System of Medicine-A Cold Desert Area of Himachal Pradesh in North Western Himalayas, India. Chinese Medicine. 2011;2:93-102.
12. Preston RJ, Dean BJ, Galloway S, et al. Mammalian in-vivo cy togenetic assays Analysis of chromosome aberrations in bone marrow cells. Mutation Research/Genetic Toxicology 1987;189(2):157165.

13. Von Ledebur M, Schmid W. The micronucleus test. Methodological aspects. Mutation research. 1973;19(1):109-117.

14. Mitscher LA, Telikepalli H, McGhee E, Shankel DM, Natural antimutagenic agents, Mutation Research, 1996;350(1):143-152.

15. Campos JMS, Davide LC, Soares GLG, Viccini LF. Mutagenic effects due allelopathic action of fern (Gleicheniaceae) extracts. Allelopath Journal. 2008;22(1):143-152.

16. Chacon DR, Dalla Libera AN, Cintra DEC, Carvalho JCT, De Oliveira GA, Maistro EL. Absence of genotoxic and antigenotoxic effects of a standardized extract of the medicinal plant Solanum melongena on peripheral blood and bone marrow cells of Wistar rats. Cytologia. 2002;67(4):417-422.

17. Ferreira L, Carvalho JCT, Maistro EL. Standardized Solanum melongena extract presents protective effects against chromosomal aberrations induced by Doxorubicin in Wistar rat bone marrow cells. Cytologia. 2003;68(2):177-181.

18. Denadai R, Lima PLA, Salvadori DMF, Eira AF, Bazo AP, Ribeiro LR. The protective effect of mushroom (Agaricus blazei) teas on the genotoxicity induced by cyclophosphamide. Genetics and Molecular Biology. 1998;21:79.

19. Marnewick JL, Gelderblom WCA, Joubert E. An investigation on the antimutagenic properties of South African herbal teas. Mutation Research. 2000;471(1-2):157-166.

20. Kaur S, Kumar S, Kaur P, Chandel M. Study of antimutagenic potential of phytoconstituents isolated from Terminalia arjuna in the Salmonella/microsome assay. American Journal of Biomedical Science. 2010;2(2):164-77.

21. Nardemir G, Yanmis D, Alpsoy L, Gulluce M, Agar G, Aslan A. Genotoxic, antigenotoxic and antioxidant properties of methanol extracts obtained from Peltigera horizontalis and Peltigera praetextata. Toxicology and Industrial Health. 2015;31:602613.

22. Durnova NA, Kurchatova MN. The Effect of Plant Extracts on the Cyclophosphamide Induction of Micronucleus In Red Blood Cells Of Outbred White Mice. Tsitologiia. 2014;57(6):452-458.

23. Prakash G, Hosetti BB, Dhananjaya BL. Antimutagenic effect of Dioscorea Pentaphylla on genotoxic effect induced by methyl methanesulfonate in the drosophila wing spot test. Toxicology International. 2014;21(3):258. 